International Research Journal of Management, IT \& Social Sciences
Available online at https://sloap.org/journals/index.php/irjmis/
Vol. 5 No. 6, November 2018, pages: 114 130
ISSN: 2395-7492
https://doi.org/10.21744/irjmis.v5n6.428

\title{
Transitivity in the Text of Indonesian Presidential Candidates Debate 2014-2019
}

\author{
Irma Setiawan ${ }^{a}$ \\ I Ketut Darma Laksana ${ }^{\text {b }}$ \\ Mahyuni $^{\mathrm{c}}$ \\ I Nyoman Udayana ${ }^{\mathrm{d}}$
}

\section{Article history:}

Received: 9 July 2018

Accepted: 30 September 2018

Published: 30 November 2018

\section{Keywords:}

candidate debate text;

ideology;

presidential debate;

presidential election;

systematic functional linguistics;

\begin{abstract}
The presidential debate is a fundamental part of a sort of presidential election events worldwide. A number of developing countries with a presidential system of government always carry out hearing, listening and tracking the vision and mission of the nation and country. This activity is conducted to introduce the presidential candidates and vice presidents to the citizens. For example, the presidential debate in Indonesia raises a variety of social phenomena of language. There are three main factors behind selecting this phenomenon of language at the 2014 presidential debate, namely: empirical, practical, and theoretical as the topic of a study. In order to answer these three phenomena, the researcher focuses on the linguistic exposure system on the Candidate Debate Text (CDT) for the presidential election. This study aims at describing deeply the various aspects of the exposure system of the linguistic experiences of the two presidential candidates of Indonesia in the debate. Moreover, this study intends to describe the scheme and the range or reach of the discussion conducted by two candidates through debate. The theory used as the basic reference of this study is Systematic Functional Linguistics (SFL) articulated by Halliday $(1985,1991,2004,2014)$.
\end{abstract}

\section{Author correspondence:}

Irma Setiawan,

Doctoral Student, Udayana University, Denpasar, Indonesia

Email address: irmasetiawan9@gmail.com

\footnotetext{
${ }^{a}$ Udayana University, Denpasar, Indonesia

${ }^{\mathrm{b}}$ Udayana University, Denpasar, Indonesia

c Mataram University, NTB, Indonesia

${ }^{\mathrm{d}}$ Udayana University, Denpasar, Indonesia
} 


\section{Introduction}

The presidential candidate debate is one of the political activities organized by a certain commission or agency appointed by a country. This acts as an essential part of a set of stages of presidential elections worldwide. All countries holding presidential democracy constitutional system conduct presidential debate as an instrument or media to recognize and understand the vision and mission of the presidential candidates. The presidential candidate debate is composed of arguments, views, or ideas to improve and develop the nation and state. The presidential candidate debate is a political act, meaning that debate is a vehicle of power. Jones \& Wareing (2007: 63) cited Orwell's (1986) assertion state that political language is constructed to shift a manipulative sound to be true, murder sounds to be noble, and nonsense sounds to be convincing. It means that the representation of reality in political conversation, such as the presidential debate needs closer and even serious attention to reveal the truth of the facts behind the speech. What do the speakers say is real or just the political promises?

\section{Phenomena of Political Debate by Presidential Candidates}

The presidential debate as a political activity conducted to gain power cannot be separated from various and numerous problems. Developing countries that adopt a presidential democratic system also often face problems. Through democratic presidential debate, Hillary Clinton and Republican presidential candidate Donald Trump in 2016 argued over taxation policies (Bhattarai et al., 2018), presidential political turmoil in Lebanon (Potter, 2016), community conflicts in the election of the governor of the province of Lagos, Nigeria (Ajilore, 2015), President Buhari's political speech in response to the parliamentary chaos in Nigeria (Koussouhon \& Dossoumou, 2015), and various political issues of presidential elections in the United States which are often racial, group or community issues, immigrant issues, and so forth (Benoit \& Airne, 2005). From some political phenomena in various regions of the world, this study makes the issue of the political debate of presidential candidates as a global issue to avoid development of black politics, money politics, and contradiction between groups, races or ethnic groups, and religions.

An example of the investigation of the phenomenon of political debate in the world is the election of presidential candidates of Indonesia in 2014. Presidential candidate of Red and White Coalition, Prabowo Subianto and Indonesia Hebat Coalition, Joko Widodo argue their own argument and opinion of the policy of economic improvement-national welfare and foreign policy-national security. The election of the presidential candidate debate in Indonesia is originally done to spark the birth of post-new reforms.

Indonesia held a democratic system of government from the reform era in 1998-1999. In 2002, the presidium of several institutions in Indonesia who have the opportunity to become president is invited to do a political competition to save and defend democracy of the reform era in Indonesia (Eriyanto, 2009). This initiation is then used as the momentum of the beginning of the presidential debate. The concrete steps of the presidential debate began to be widely publicized and criticized by Indonesian people in the presidential election 2004-2009, then continued in 2009-2014 and 2014-2019. Consequently, the activity of debating in Indonesia has been formally held three times. From each of the debates, there is always a political issue in the name of communities or groups, races, religions, and so on to attack political opponents. Therefore, based on several issues concerning on the function and nature of language in political conversation, there are three factors found as the rationales behind doing a study related to the phenomenon of language in the presidential debate in the presidential election in 2014, namely empirical, practical, and theoretical.

The empirical phenomenon that attracted attention in organizing a presidential debate in 2014 is the social attitude of the language of the presidential candidates, the involvement of the media in the process of winning the presidential candidate, and the political and social conditions of the society. Various linguistic contents of the presidential candidate which are persuasive and euphemism precisely raise an attitude of excessive fanaticism in society. As a result, Indonesian society is divided into pros and cons coalition. The same thing happens to the smallest community in society, namely family life (household). The family members split into two group due to different attitudes and perceptions of the presidential candidates. Academicians as well as political observers, Purba (Okezone, 23/3/14) describes this phenomenon in the national media news headline entitled "Warring with Your Own Brother" which essentially alludes to horizontal conflicts of Indonesian society due to the influence of the presidential election in 2014. The involvement of media in playing political issues to favor or weaken one of the presidential candidates further aggravates the 2014 presidential site. The media tends to intervene and lead to voter perceptions through political languages. Eriyanto (2012: 32) claims that the media is only dominated by dominant groups and become a means to discredit other groups.

Setiawan, I., Laksana, I. K. D., Mahyuni, -, \& Udayana, I. N. (2018). Transitivity in the text of Indonesian presidential candidates debate. International Research Journal of Management, IT and Social Sciences, 5(6), 114-130. https://doi.org/10.21744/irjmis.v5n6.428 
A practical phenomenon in organizing a presidential debate in 2014 that attracted the attention of researchers is the language practice of the presidential candidates, the procedure of debate, and the mechanism of a debate broadcast on the television media. Both candidates' language strategies tend to leverage personal experiences to build a nation. The contents of the debate of the presidential candidates are largely sourced from survey evidence according to their own expert team without any comparison so that it can lead to the subjective claims. The activities of the presidential debate are held by the General Election Commission (GEC) directly supervised by the Election Supervisory Board. Broadcasting the presidential debate must be guarded by the public. In this case, the researcher is obliged to do monitoring and analyzing, especially to the mechanism of organizing event funded by the state. The researcher's attitude controlled the debate show based on article 17 paragraph 2 in Law No. 40 the Year 1999 impressing on public participation in overseeing media broadcasts, including print and electronics.

The theoretical phenomenon that encourages researchers to analyze the presidential debate 2014 is a scheme of linguistic experience and lacks some related previous research. Halliday (2014: 13) states in the study of Systemic Functional Linguistic that linguistic experience stems from non-linguistic experiences communicated by participants called as a text. The existence of the text cannot be interpreted without the presence of context. Therefore, linguistic experience in the study of Systematic Functional Linguistics is constructed from the text and its context with elements of analysis including type, scope, value, and orientation. Based upon this, these recent years research on the study of texts and contexts based on the theory of Systematic Functional Linguistics, such as: Bhattarai et al., (2015), Potter (2016), Ajilore (2015), Koussouhon \& Dossoumou (2015), and Benoit \& Airne (2005) are the five studies remaining gaps that have not been discovered previously, namely the debate scheme that contains the level - dominance and the range or reach of clauses of language based on the study of the theory of Systematic Functional Linguistics.

The fifth methodological concept of the aforementioned research mostly refers to the concept of Firth which is claimed as the most influential concept in Europe. Firth idea is dominantly influenced by some structural linguistic theories of Saussure, Hjemslev, Malinowski, and the ideology of Prague (Sinar, 2012: 14). Firth's view seeks to look at the language in its use and to look at functions on the basis of the various systems in the language. This is the one developed by the Pragueits who see the function of language derived from interrelated forms, systems (structures), mutual determination, and stratification (Young, 2011: 625).

The novelty of this research is to analyze the schemes and range of the utterances delivered both candidates in a presidential debate based on the transitivity system which includes text analysis in the form of process, participants, and circumcision. The three units of analysis of transitivity systems have analytical elements such as (1) the process including material, mental, relational, behavioral, verbal, and existential analysis; (2) participants including the main participants (participants I and II) and other participants, 3) Circumstance including time and place extent, location of time and place, way, contingency, cause, angle, matter, and source. The overall analysis of the transitivity system is presented based on the analytical tools that have the nature of the process of high - low realization, the nature of single and plural participants, inclusive and exclusive. The context analysis is used to investigate ideological motives in the text of the presidential debate based on the cultural and situational context.

The expected result of this study is obtaining the schematic and the range of clauses of the utterance from the linguistic presentation system of presidential candidate namely Prabowo Subianto (PB) and Joko Widodo (JW) on the text of the presidential debate of the Republic of Indonesia 2014 - 2019. Based upon this, the exposure of the linguistic experience aims at describing the transitivity system which includes analysis of processes, participants, circumstance, and the range or reaches of the three elements of systemic analysis. The use of range on the process, participant, and circumstance analysis can represent the focus and direction of the policies of both candidates.

Based on the above empirical, practical, and theoretical phenomena, this study becomes very interesting to conduct grounded in the theory of Systematic Functional Linguistics. The researcher analyzed the function of linguistic experience exposure. Next, the researcher analyzed the ideological contents based on the social context of the text. The research presented is intended to explore and map the scheme and the content on the 2014 presidential debate text. In addition, the study of the text of political debate based on the theory of Systematic Functional Linguistics has never been conducted by previous researchers so that this study is expected to be one of the analytical formulas and additional variations to the method of discourse investigation, especially to oral text, such as the text of the presidential debate.

\section{Systemical Functional Linguistics as A Discourse Analysis Tool}

SFLT is a model of linguistic study articulated by Halliday $(1985 ; 1991 ; 2004 ; 2014)$ of the University of Sydney - Australia. Halliday absorbed many teaching linguistic theories from European linguists, such as Firth (English). The development of Halliday's ideology is dominantly influenced by the linguistic principle of the Prague Flow. Young 
(2011: 625) describes the views of the Ideology of Prague on several things in linguistic theory, namely: (a) the view of language as an interconnected network, (b) the view of language as a system consisting of multilevel or stratified sub-systems, (c) the more emphasis on the functional aspects of the language, and (d) the existence of the existence or form view coming from the function. SFLT main focus lies in language relation with context. SFLT is based on two basic concepts that distinguish it from other linguistic theories, namely; (a) language is a social phenomenon in the form of social semiotics and (b) language is a text that is in strong relation with the social context so that the study of language is never independent of the social context. The SFLT has been discussed in the last four editions of Halliday's book $(1985 ; 1991 ; 2004 ; 2014)$.

Halliday (2004: 1) defines that the text must be considered in two main visions; 1) focus on the text as an object in itself and 2) focus on the text as a tool to find out something else. As a result, the text can declare itself through the text's content and any text can encourage a person to understand the meaning beyond the text, i.e. the context. The realization of a non-linguistic experience into a language experience (linguistic) in which language as a means of interaction is called as a metafunction. Saragih (2006: 6) explains that the metafunction as the basic function of language in its use by speakers of the language. Language has a role to realize a speaker's linguistic experience. Various messages and meanings, either expressed or implied, can be contained in the speaker's language. Halliday (1991: xiii); Eggins (1994: 3); Sinar (2012: 27) state that the metaphor of language consists of three parts, namely the function of exposure, exchange, and sequencing or organizing. Therefore, in accordance with this study, the part of the language metafunction being the focus of this study is the system of linguistic experience exposure through text transitivity analysis. This analysis then undergoes the process of adaptation into a tool of identification of text, such as CDT in 2014.

\section{Materials and Methods}

The research approach used in this study is qualitative research design aiming at describing and analyzing the transitivity system, situational context, and cultural context. Hence, a detailed understanding of the scheme and the discussion of the two candidates during the debate can be obtained.

Types of research data in the form of oral data which is then transcribed wholly so that data form such as words, phrases, group phrases, clauses, and text units can be obtained. The whole data come from the utterances of the candidates during the debate. Data transcripts or CDT 2014 serve as the primary data of research because the data were obtained by researchers directly from the data source. While secondary data are in the form of supporting data analysis that comes from written text or library.

The data source in this study comes from the audio-visual tapes (video) of 2014 presidential debate that are broadcasted through television. The debate video is divided into five rounds, namely: first round of presidential debate and vice-presidential stage I, second round of the first stage of the debate, the third round of the second stage of the debate, the fourth round of the first stage of the debate, and the fifth round of the presidential and vice-presidential debate stage II.

The research instrument is divided into two, namely the main and supporting instruments. The main instrument in this study is the researcher himself as a human resource in the study. In this case, the researcher uses a validation instrument in the form of functional validation table to observe the systematic functioning of every text forming elements, such as words, phrases, groups, and clauses. Furthermore, supporting instruments are more in the form of supporting equipment in searching, collecting, determining, and analyzing data.

This research uses the descriptive method because the data is collected qualitatively by describing the language scheme and the subject of presidential talk on debate text of 2014. To describe text units and context in 2014 presidential debate text, several data collection methods are used, namely documentation and observation method. The method of analysis used by the researcher is inductive, meaning that the method of thinking in this study departs from the rules that are specific to determine the general principle. The analytical technique used is a qualitative technique because the collected data is processed and analyzed descriptively. Miles \& Huberman (1992: 16) propose an interactive and comprehensive step of analysis covering the steps of reduction, presentation, and verification.

Method of data presented in this research uses a general and special method. The general method is intended to present all forms of speech in research in the form of numbers and descriptions of words, phrases, group phrases, clauses, units of text, and text. Furthermore, special methods are intended for the presentation of research in the form of symbols or signs (Mahsun, 2007: 123 and Sudaryanto, 2015: 144).

Setiawan, I., Laksana, I. K. D., Mahyuni, -, \& Udayana, I. N. (2018). Transitivity in the text of Indonesian presidential candidates debate. International Research Journal of Management, IT and Social Sciences, 5(6), 114-130. https://doi.org/10.21744/irjmis.v5n6.428 


\section{Results and Discussions}

The discussion in this research includes descriptions of analysis results on linguistic exposure systems such as process analysis, participants, circumstance, and ideological representation. Each component of the analysis is elaborated based on the scheme and the range of utterances of both candidates, namely Prabowo Subianto (PS) and Joko Widodo (JW). Then, the analysis is focused on Candidate Debate Text (CDT) I and II obtained from the live television broadcasts on Metro TV and TV One, both of which received broadcasting rights from the General Election Commission (GEC). The selection of CDT I and II as the object of study is because these two texts only present the debates done by both candidates. In accordance with the focus of research that only describes the language scheme and language range of the candidates. In addition, the position of presidential candidates in the presidential election became the most decisive main figure elected or not in the presidential election. From the results of the analysis, we can describe several discussion topics, namely: 1) process system, 2) participants, 3) circumstance, and 4) ideology of the representation on CDT I and II.

\subsection{Process System}

Process analysis within the transitivity system is an attempt to explain the activities, behaviors, situations, and conditions of discourse in the text. The activity can be realized through several types of processes initiated by Halliday (2014: 213) which describes two process groups, namely the primary and secondary processes. Primary process includes material, mental, and relational processes, while the second process consists of behavioral, verbal, and existential processes. However, based on the research material, the pattern of process sharing has been adopted, namely the high realization process and the low realization process. The high realization process is a behavioral realization based on empirical, factual, and incidental experiences. Meanwhile, the low process is only a realization of action based on verbal assumptions and is the realization between each entity in the interaction, so it is considered less factual, empirical, and memorable. The process of high realization consists of material, mental, behavioral, and existential processes, while the process of low realization includes relational and verbal process. The description of both types of processes is presented as follows.

a) The Scheme and Reach of High Realization Process

The second statement scheme of candidates on CDT I and II show the difference in the number of utterances. PS and JW use the structure of utterances starting from behavioral, existential, material, and mental process. However, by number, JW dominates the use of all four processes in which JW's utterances have a more detailed potential of the range or reach. Each process used by both candidates is divided into two categories of statements, namely: active (transitive and intransitive) and passive. Both categories of this statement determine the reach of the respective policy of each candidate. For example, a material process statement with a transitive active category requires a statement, whereas intransitive material does not require a point of utterance. This can be seen in Table 1 below picturing the scheme of high Realization process by both candidates.

Table 1

Level of the use of high realization process by both presidential candidates

\begin{tabular}{|c|c|c|c|c|c|c|c|c|}
\hline \multicolumn{3}{|c|}{ Presidential Candidate } & \multicolumn{3}{|c|}{ PS } & \multicolumn{3}{|c|}{ JW } \\
\hline \multirow[t]{2}{*}{ No. } & \multirow[t]{2}{*}{ Type of Process } & \multirow[t]{2}{*}{ Process structure } & $\mathrm{TD}$ & $\mathrm{TD}$ & $(\%)$ & TDC & TDC & $(\%)$ \\
\hline & & & $\mathrm{C} \mathrm{I}$ & C II & & I & II & \\
\hline \multirow[t]{5}{*}{1} & \multirow[t]{5}{*}{ Material } & \multicolumn{7}{|l|}{ a. Active: } \\
\hline & & - Transitive & 64 & 55 & $-8 \%$ & 57 & 45 & $-12 \%$ \\
\hline & & - Intransitive & 9 & 3 & $-50 \%$ & 6 & 1 & $-72 \%$ \\
\hline & & b. Passive & 5 & 7 & $+16 \%$ & 52 & 20 & $-44 \%$ \\
\hline & & Total Number & 78 & 65 & & 115 & 66 & \\
\hline \multirow[t]{4}{*}{2} & \multirow[t]{4}{*}{ Mental } & a. Active: & & & & & & \\
\hline & & - Transitive & 20 & 48 & $+41 \%$ & 44 & 53 & $+9 \%$ \\
\hline & & - Intransitive & 13 & 21 & $+24 \%$ & 9 & 10 & $+6 \%$ \\
\hline & & b. Passive & 1 & 16 & $+87 \%$ & 4 & 20 & $+66 \%$ \\
\hline
\end{tabular}




\begin{tabular}{|c|c|c|c|c|c|c|c|c|}
\hline \multicolumn{3}{|c|}{ Total Number } & 34 & \multicolumn{2}{|l|}{85} & 56 & \multicolumn{2}{|l|}{83} \\
\hline \multirow[t]{5}{*}{3} & Behavioural & a. Active: & & & & & & \\
\hline & & - Transitive & 17 & 54 & $+52 \%$ & 35 & 39 & $+6 \%$ \\
\hline & & - Intransitive & 35 & 48 & $+16 \%$ & 47 & 59 & $+12 \%$ \\
\hline & & b. Passive & 5 & 16 & $+52 \%$ & 22 & 22 & tetap* \\
\hline & & nber & 57 & 118 & & 104 & 120 & \\
\hline \multirow[t]{5}{*}{4} & Existential & a. Active: & & & & & & \\
\hline & & - Transitive & 36 & 5 & $+76 \%$ & 12 & 5 & $-42 \%$ \\
\hline & & - Intransitive & 51 & 61 & $+9 \%$ & 78 & 92 & $+8 \%$ \\
\hline & & b. Passive & 5 & 8 & $+23 \%$ & 14 & 6 & $-40 \%$ \\
\hline & & nber & 92 & 74 & & 104 & 103 & \\
\hline $\begin{array}{l}+: \\
-:\end{array}$ & $\begin{array}{l}\text { ment } \\
\text { ement }\end{array}$ & & & & & & & \\
\hline
\end{tabular}

Table 1 presents the level of the use of high realization of utterances delivered by both candidates. PS and JW's utterances schemes show the increment and decrement of the process used. The consistency of increasing the use of the process by the two candidates only occurs in behavior and mental process, while the material and the existential process are fluctuating.

The difference in the scheme of utterances on both candidates lies only in the number of the use of the process. JW more dominates the use of the whole high realization process. It indicates that JW has a wider variety and wider range (high reach) of statements than PS has. In addition, the JW statement has more high realization so that the potential to realize the policy is more soundful and actual than the PS statement has.

The scheme of utterances also affects the range of the utterances or statements of both presidential candidates. The high level of use of the process determines the policy focus that will be realized by both candidates. Therefore, the high-reach of utterances delivered by PS and JW have their own range or reach of processes. The reach of the utterances with high realization process delivered by both candidates can be seen in this Table 2 below.

Table 2

High reach of realization process by presidential candidates PS and JW

\begin{tabular}{llllll}
\hline \multirow{2}{*}{ No. } & Type of Process & \multicolumn{2}{c}{ PS } & \multicolumn{2}{c}{ JW } \\
\cline { 3 - 6 } 1 & \multirow{2}{*}{ Material } & TDC I & TDC II & TDC I & TDC II \\
& & membangun & mengamankan & membangun & memberikan \\
& bekerja & mempertahankan & memberikan & dilatih \\
2 & Mental & mengerti & butuh & kira & kira \\
& & bayangkan & mengerti & menghormati & mengedepankan \\
3 & Behavioural & membiarkan & yakinkan & melakukan & lakukan \\
& & mengamankan & bersahabat & hemat & kerjakan \\
4 & Existential & meningkatkan & ada & menguntungkan & mengurangi \\
& & bocor & bocor & meningkatkan & ada \\
\hline
\end{tabular}

Table 2 lists the range of utterance produced by both candidates on CDT I and II. The tendency of utterances produced by PS shows the use of the process: a) material: membangun (building), bekerja (working), mengamankan (securing) and mempertahankan (sustaining), b) mental: mengerti (understanding), membayangkan (imagining), and butuh (needing), c) behavior: membiarkan (letting), mengamankan (securing), yakinkan (convincing), and bersahabat (being friendly), d) Existential: meningkatkan (increasing), bocor (being leak), and ada (existing). Then the subject of the utterances delivered by JW is the use of the process: a) material: membangun (building), memberikan (giving) and dilatih (being trained), b) mental: kira (thinking), menghargai (respecting), and mengdepankan (putting forward), c) behavior: melakukan (doing), hemat (being economical), lakukan (doing) and kerjakan (doing) d) existential: mengurangi (reduce), meningkatkan (increasing), and ada (existing). The example clause as follows.

Setiawan, I., Laksana, I. K. D., Mahyuni, -, \& Udayana, I. N. (2018). Transitivity in the text of Indonesian presidential candidates debate. International Research Journal of Management, IT and Social Sciences, 5(6), 114-130. https://doi.org/10.21744/irjmis.v5n6.428 
(1) “Kami akan membangun 3.000 KM jalan raya/ 4.000 KM kereta api/ 8 pelabuhan//” (TI.PS-1.31)

(We will build 3,000 KM highway / 4,000 KM railway / 8 ports //)

\begin{tabular}{ccccc}
\hline $\begin{array}{l}\text { Kami } \\
(\text { We) }\end{array}$ & $\begin{array}{l}\text { akan } \\
\text { (will) }\end{array}$ & $\begin{array}{l}\text { membangun } \\
\text { (build) }\end{array}$ & $\begin{array}{l}3.000 \mathrm{~km} \text { jalan raya/4.000 km kereta api/ } 8 \text { pelabuhan } \\
(3,000 \mathrm{KM} \text { highway / 4,000 KM railway / 8 ports //" } \\
(\text { TI.PS-1.31) }\end{array}$ \\
\hline $\mathrm{N}$ & Adv. & V-trans. & G.N \\
Actor & Manner & Material Prs. & Goal \\
\hline
\end{tabular}

(2) "Saya bertemu pak Abdulah nelayan dari Belawan di Sumatra Utara/” (TI.JW-1.5) (I met Mr. Abdullah, a fisherman from Belawan in North Sumatra)

\begin{tabular}{ccccc}
\hline $\begin{array}{l}\text { Saya } \\
(\mathbf{I})\end{array}$ & $\begin{array}{l}\text { bertemu } \\
\text { (meet) }\end{array}$ & $\begin{array}{l}\text { pak Abdullah } \\
\text { (Mr. Abdullah) }\end{array}$ & $\begin{array}{l}\text { nelayan } \\
\text { (fisherman) }\end{array}$ & $\begin{array}{l}\text { dari Belawan di Sumatera Utara } \\
\text { (from Belawan in North Sumatra) }\end{array}$ \\
\hline \multicolumn{1}{c}{$\mathbf{N}$} & V-intrans. & Range & $\mathrm{N}$ & G.Adv. \\
Actor & Material Prs. & Goal & Role & $\begin{array}{c}\text { Source/ } \\
\text { Place of location }\end{array}$ \\
\hline
\end{tabular}

(3) Kita mengerti [tujuan negara] //” ((TI.PS-1.2)

(We understand [the purpose of the country])

\begin{tabular}{ccc}
\hline $\begin{array}{l}\text { Kita } \\
(\text { We })\end{array}$ & $\begin{array}{l}\text { mengerti } \\
\text { (understand) }\end{array}$ & $\begin{array}{l}\text { tujuan negara } \\
\text { (the purpose of the country]) }\end{array}$ \\
\hline N & V-intras. & $\mathrm{N}$ \\
Senser & Mental Prs. & Phenomena \\
\hline
\end{tabular}

(4) “Saya kira dukungan-dukungan seperti inilah//” (TI.JW-3.21)

(I think it's the supports like these //)

\begin{tabular}{|c|c|c|c|c|}
\hline $\begin{array}{l}\text { Saya } \\
\text { (I) }\end{array}$ & $\begin{array}{l}\text { kira } \\
\text { (think) }\end{array}$ & $\begin{array}{l}\text { dukungan-dukungan } \\
\text { (supports) }\end{array}$ & $\begin{array}{l}\text { seperti } \\
\text { (like) }\end{array}$ & $\begin{array}{l}\text { (Inilah) } \\
\text { these }\end{array}$ \\
\hline $\mathbf{N}$ & $\mathrm{N} \rightarrow \mathrm{V}$-intrans. & G.N & Conj.Dmns. & Dmns. \\
\hline Senser & Mental Prs. & Phenomena & & \\
\hline
\end{tabular}

(5) “...Kita juga akan meyakinkan bangsa lain//” (TII.PS-3.33)

(... We will also convince other nations //)

\begin{tabular}{|c|c|c|c|c|}
\hline $\begin{array}{l}\text { Kita } \\
\text { (We) }\end{array}$ & $\begin{array}{l}\text { juga } \\
\text { (also) }\end{array}$ & $\begin{array}{l}\text { akan } \\
\text { (will) }\end{array}$ & $\begin{array}{l}\text { meyakinkan } \\
\text { (convince) }\end{array}$ & $\begin{array}{l}\text { bangsa lain } \\
\text { (other nations) }\end{array}$ \\
\hline $\mathbf{N}$ & Conj. Adv. & Adv. & V-trans. & $\mathrm{N}$ \\
\hline Behaver & \multicolumn{2}{|c|}{ Manner } & Behavioural Prs. & Realisation \\
\hline
\end{tabular}

(6) "Proses diplomasi yang ingin kita lakukan//” (TII.JW-14.7)

(the diplomacy procces we want to do)

\begin{tabular}{ccccccc}
\hline $\begin{array}{l}\text { Proses } \\
\text { (process) }\end{array}$ & $\begin{array}{l}\text { diplomasi } \\
\text { (diplomacy) }\end{array}$ & $\begin{array}{l}\text { yang } \\
\text { (that) }\end{array}$ & $\begin{array}{l}\text { ingin } \\
\text { (want) }\end{array}$ & $\begin{array}{l}\text { kita } \\
\text { (we) }\end{array}$ & $\begin{array}{l}\text { lakukan } \\
\text { (to do) }\end{array}$ \\
\hline N & \multirow{2}{*}{ Range } & & Conj.Adv. & Adv. & N & V-intrans. \\
& Ranger & \multicolumn{2}{c}{ Manner } & Behaver & Behavioural Prs. \\
\hline
\end{tabular}

(7) “Uang akan ada kalo ekonomi baik//” (TII.PS-4.39)

("Money will be gotten if the economy is good //")

\begin{tabular}{|c|c|c|c|c|c|}
\hline $\begin{array}{c}\text { Uang } \\
\text { (Money) }\end{array}$ & $\begin{array}{l}\text { akan } \\
\text { (will) }\end{array}$ & $\begin{array}{l}\text { ada } \\
\text { (exist) }\end{array}$ & $\begin{array}{l}\text { kalo } \\
\text { (if) }\end{array}$ & $\begin{array}{l}\text { Ekonomi } \\
\text { (economy) }\end{array}$ & $\begin{array}{l}\text { baik } \\
\text { (good) }\end{array}$ \\
\hline $\mathbf{N}$ & Adv. & V-intrans. & Conj.N & $\mathrm{N}$ & Adj. \\
\hline Existent & Manner & Existential Prs. & & Manner & \\
\hline
\end{tabular}


(8) "[Diplomasi] inilah yang akan mengurangi konflik-konflik//” (TII.JW-16.8) (this diplomacy that will reduce the conflicts //)

\begin{tabular}{|c|c|c|c|c|c|}
\hline $\begin{array}{l}\text { Diplomasi } \\
\text { (Diplomacy) }\end{array}$ & $\begin{array}{l}\text { inilah } \\
\text { (these) }\end{array}$ & $\begin{array}{l}\text { yang } \\
\text { (that) }\end{array}$ & $\begin{array}{l}\text { akan } \\
\text { (will) }\end{array}$ & $\begin{array}{l}\text { mengurangi } \\
\text { (reduce) }\end{array}$ & $\begin{array}{l}\text { konflik-konflik } \\
\text { (conflicts) }\end{array}$ \\
\hline $\mathbf{N}$ & Dmns. & Conj.Adv. & Adv. & V-trans. & $\mathrm{N}$ \\
\hline \multicolumn{2}{|c|}{ Existent } & \multicolumn{2}{|c|}{ Manner } & Existential Prs. & Realisation \\
\hline
\end{tabular}

Clauses 1 - 8 are the examples gathered from of the utterances produced by both candidates in CDT I and II. Utterances no. 1 - 2 contain the use of high-reach of material processes in PS and JW utterances. PS proposed the policy of development of land and sea infrastructure, while JW has made a move to the region to know the condition of Indonesian people directly. Clauses 3 - 4 show the PS proposing a policy based on the state's goal of prospering and the welfare of the Indonesian people. Then JW considers the importance of government support to market traders and street vendors so that economic growth can start from the micro-economic sector to the macroeconomic sector. Clauses 5 - 6 show the PS affirmation of the importance of communicating with other countries since communication activities can increase the confidence of other nations to establish a friendship, bilateral relations, and so forth. Furthermore, the JW statement highlights the strategy of territorial conflict resolution as the case of the South China Sea requires a policy solution by strengthening diplomacy among countries.

b) Scheme and Reach of Low Realization Process

The scheme and low reach of realization process on the PS and JW's utterances show similar schemes with a different number of users. Similar to the high- realization process aforementioned earlier that in the low- realization process, the scheme of the utterances of both candidates is a relational process and a verbal process. A description of low- realization process data can be seen in the following table 3 below.

Table 3

Level of use of low realization process by both presidential candidates

\begin{tabular}{|c|c|c|c|c|c|c|c|c|}
\hline \multicolumn{3}{|c|}{ Presidential Candidate } & \multicolumn{3}{|c|}{ PS } & \multicolumn{3}{|c|}{ JW } \\
\hline \multirow[t]{2}{*}{ No. } & \multirow[t]{2}{*}{ Type of Process } & Process Structure & TD & TD & $(\%)$ & TDC & TDC & $(\%)$ \\
\hline & & & C I & C II & & I & II & \\
\hline \multirow[t]{9}{*}{1} & \multirow[t]{8}{*}{ Relational } & a. Active: & & & & & & \\
\hline & & - Identifying & 29 & 25 & $-7 \%$ & 33 & 35 & $+3 \%$ \\
\hline & & - Attributive & 16 & 23 & $+17 \%$ & 17 & 21 & $+11 \%$ \\
\hline & & - Possessive & 14 & 27 & $+32 \%$ & 26 & 22 & $-8 \%$ \\
\hline & & Passive: & & & & & & \\
\hline & & - Identifying & - & 1 & $+100 \%$ & 1 & 1 & tetap* \\
\hline & & - Attributive & 1 & - & $-100 \%$ & 3 & - & $-100 \%$ \\
\hline & & - Possessive & - & - & - & - & - & tetap* \\
\hline & \multicolumn{2}{|c|}{ Total Number } & 60 & 76 & & 81 & 79 & \\
\hline \multirow[t]{5}{*}{2} & \multirow[t]{5}{*}{ Verbal } & a. Active: & & & & & & \\
\hline & & - Transitive & 24 & 23 & $-2 \%$ & 20 & 20 & tetap* \\
\hline & & - Intransitive & 11 & 20 & $+29 \%$ & 6 & 5 & $-9 \%$ \\
\hline & & b. Passive: & 7 & 1 & $-75 \%$ & 2 & 2 & tetap* \\
\hline & & umber & 42 & 44 & & 28 & 27 & \\
\hline
\end{tabular}

Table 3 shows the level of use of high- realization processes by presidential both candidates PS and JW. In terms of uttering scheme, both candidates have the same pattern of utterance, but in terms of number, JW dominates the use of the relational process, while PS dominates the use of the verbal process. It indicates that JW utterances tend to associate one entity with another entity in each of his policies. Besides, PS often uses statements containing information to debate partners or the community on the recommendation of their own expert team, so that the information presented tends to be subjective. Furthermore, the level of the process used affects the range or reach of the utterance of both

Setiawan, I., Laksana, I. K. D., Mahyuni, -, \& Udayana, I. N. (2018). Transitivity in the text of Indonesian presidential candidates debate. International Research Journal of Management, IT and Social Sciences, 5(6), 114-130. https://doi.org/10.21744/irjmis.v5n6.428 
candidates. From the results of the analysis, the researcher obtained the utterances produced by both presidential candidates that can be categorized into low realization process. It can be seen in table 4 below.

Table 4

Reach of Low- Realization Process of Presidential Candidates PS dan JW

\begin{tabular}{llllll}
\hline \multirow{2}{*}{ No. } & \multicolumn{1}{c}{ Type of Process } & \multicolumn{2}{c}{ PS } & \multicolumn{2}{c}{ JW } \\
\cline { 3 - 6 } $\mathbf{1}$ & & \multicolumn{1}{c}{ TDC I } & \multicolumn{1}{c}{ TDCII } & \multicolumn{1}{c}{ TDC I } & TDCII \\
& Relational: & adalah & adalah & adalah & menyangkut \\
& - Identifying & membutuhkan & & merupakan & adalah \\
& - Attributive & menjadi & menjadi & menjadi & menjadi \\
& - Milik & punya & punya & mempunyai & mempunyai \\
$\mathbf{2}$ & Verbal & mengatakan & Menurut & sampaikan & sampaikan \\
& & membahas & bicara & menurut & menurut \\
\hline
\end{tabular}

Table 4 shows the verbal range of utterances used by PS and JW in CDT I and II. PS has an affluent utterance on: a) relational process in the form of: identifying verb: adalah (is/am/are) and membutuhakn (needing), attributive verb: menjadi (being/becoming), and possessive verbs: punya (have/has) and b) verbal processes: mengatakan (saying), membahas (discussing), menurut (following), and biscara (talking). Then the JW affair utterance is in the use of: a) relational process: identifying verb: adalah (is/am/are), merupakan (is/am/are), and menyangkut (relating), attributive verb: menjadi (being/becoming), possessive verb: mempunyai (has/have) and b) verbal process: sampaikan (conveying) and menurut (following). The example of clauses produced by both presidential candidates namely PS and JW that can be categorized into of low-realization process are presented as follows:

(9) “[Ekonomi rakyat] ini adalah strategi kita//” (TI.PS-2.23)

(this [Populist Economy] is our strategy)

\begin{tabular}{cccccc}
\hline $\begin{array}{l}\text { Ekonomi rakyat } \\
\text { (Populist Economy) }\end{array}$ & $\begin{array}{l}\text { ini } \\
\text { (this) }\end{array}$ & $\begin{array}{l}\text { adalah } \\
\text { (is) }\end{array}$ & strategi & \multicolumn{1}{c}{$\begin{array}{l}\text { kita } \\
\text { (strategy) }\end{array}$} & (our) \\
\hline N & Dmns. & V-trans. & $\mathrm{N}$ & $\mathrm{N}$ \\
Token & & Identifying Relational Prs. & Value & Range \\
\hline
\end{tabular}

(10) “[Hal paling penting] adalah sistemnya//” (TI.JW-3.5)

[the most important thing] is the system.

\begin{tabular}{cccc}
\hline $\begin{array}{l}\text { Hal } \\
\text { (thing) }\end{array}$ & $\begin{array}{l}\text { paling penting } \\
\text { (the most important) }\end{array}$ & $\begin{array}{l}\text { adalah } \\
\text { (is) }\end{array}$ & $\begin{array}{l}\text { sistemnya } \\
\text { (the system) }\end{array}$ \\
\hline $\mathbf{N}$ & Adj. & Vtrans. & N \\
Token & Roke & Identifying Relational Prs. & Value \\
\hline
\end{tabular}

(11) “Kita akan menjadi negara kuat//” (TI.PS-1.44)

(We will be a strong country)

\begin{tabular}{|c|c|c|c|c|}
\hline $\begin{array}{l}\text { Kita } \\
\text { (we) }\end{array}$ & $\begin{array}{l}\text { akan } \\
\text { (will) }\end{array}$ & $\begin{array}{l}\text { menjadi } \\
\text { (be) }\end{array}$ & $\begin{array}{l}\text { negara } \\
\text { (country) }\end{array}$ & $\begin{array}{l}\text { kuat } \\
\text { (strong) }\end{array}$ \\
\hline $\mathbf{N}$ & Conj. V & $\mathrm{V}$-trans. & $\bar{N}$ & Adj. \\
\hline Senser & At & Ive Relational Prs. & Attribute & Role \\
\hline
\end{tabular}

(12) “Waktu [saya] menjadi Gubernur//” (TI.JW-2.7)

(When [I] was a Governor//)

\begin{tabular}{ccccc}
\hline $\begin{array}{c}\text { Waktu } \\
\text { (when) }\end{array}$ & $\begin{array}{l}\text { saya } \\
\text { (i) }\end{array}$ & & $\begin{array}{l}\text { menjadi } \\
\text { (was) }\end{array}$ & $\begin{array}{c}\text { gubernur } \\
\text { (governor) }\end{array}$ \\
\hline $\mathbf{N}$ & & $\mathrm{N}$ & Attributive Relational Prs. & $\mathrm{N}$ \\
Range & & Senser & Attribute \\
\hline
\end{tabular}


(13) "Kita masih punya 77 juta hektar hutan yang sudah rusak //” (TI.PS-3.17) (We still have 77 Million hectares degraded forest//)

\begin{tabular}{|c|c|c|c|c|c|}
\hline $\begin{array}{l}\text { Kita } \\
\text { (we) }\end{array}$ & $\begin{array}{l}\text { masih } \\
\text { (still) }\end{array}$ & $\begin{array}{r}\text { punya } \\
\text { (have) }\end{array}$ & $\begin{array}{l}77 \text { juta hektar hutan } \\
\text { ( } 77 \text { million hectares of } \\
\text { forest) }\end{array}$ & $\begin{array}{l}\text { yang } \\
\text { (that) }\end{array}$ & $\begin{array}{l}\text { sudah rusak } \\
\text { (degraded) }\end{array}$ \\
\hline $\mathbf{N}$ & Adv. & V-trans. & G.N & Conj.Adv. & Adv. \\
\hline Owner & Time of location & $\begin{array}{c}\text { Possessive } \\
\text { Relational prs. }\end{array}$ & property & Con & ngency \\
\hline
\end{tabular}

(14) “Kita kan mempunyai sebuah daya saing//” (TI.JW-1.26) (We have a competitiveness//)

\begin{tabular}{rcc}
\hline $\begin{array}{l}\text { Kita } \\
\text { (We) }\end{array}$ & $\begin{array}{l}\text { kan mempunyai } \\
\text { (have) }\end{array}$ & $\begin{array}{l}\text { sebuah daya saing } \\
\text { (competitiveness) }\end{array}$ \\
\hline Owner & Possessive Relational Prs. & G.N \\
Owoperty \\
\hline
\end{tabular}

(15) “Masalahnya menurut saya itu agak terlalu teoritis+//” (TII.PS-19.3) (the problem is I think that is a bit too theoretical//)

\begin{tabular}{ccccccc}
\hline $\begin{array}{c}\text { masalahnya } \\
\text { (the problem) }\end{array}$ & $\begin{array}{l}\text { menurut } \\
\text { (think) }\end{array}$ & $\begin{array}{l}\text { saya } \\
\text { (i) }\end{array}$ & $\begin{array}{l}\text { itu agak } \\
\text { (a bit) }\end{array}$ & $\begin{array}{l}\text { terlalu } \\
\text { (too) }\end{array}$ & $\begin{array}{l}\text { teoritis } \\
\text { (theoretical) }\end{array}$ \\
\hline $\begin{array}{c}\text { N } \\
\text { Verbiage }\end{array}$ & V-trans. & Verbal Prs. & Sayer & Adv. & Adv. & Adj. \\
\hline
\end{tabular}

(16) “...Mengenai Indosat... ini perlu kami sampaikan bahwa saat itu tahun 1998 itu krisis berat krisis berat+//” (TII.JW-9.18)

(About Indosat... We need to convey that this was in 1998 when it was extreme crisis... extreme crisis//)

\begin{tabular}{|c|c|c|c|c|c|c|}
\hline $\begin{array}{l}\text { Mengenai } \\
\text { Indosat } \\
\text { (About Indosat) }\end{array}$ & $\begin{array}{l}\text { kami } \\
\text { (we) }\end{array}$ & $\begin{array}{l}\text { sampaikan } \\
\text { (convey) }\end{array}$ & $\begin{array}{l}\text { bahwa } \\
\text { (that) }\end{array}$ & $\begin{array}{l}\text { saat itu } \\
\text { (that } \\
\text { time) }\end{array}$ & $\begin{array}{l}\text { tahun } \\
1998 \text { itu } \\
\text { (in 1998) }\end{array}$ & $\begin{array}{l}\text { krisis berat krisis berat } \\
\text { (extreme crisis) } \\
\text { (extreme crisis) }\end{array}$ \\
\hline Adv. & $\mathrm{N}$ & V-trans. & Conj.N & $\mathrm{N}$ & $\mathrm{N}$ & Adj. \\
\hline Matter & Sayer & Verbal Prs. & \multicolumn{3}{|c|}{ Location of time } & Manner \\
\hline
\end{tabular}

The clause of the utterances no. 9 - 16 are categorized into a low -realization process used by PS and JW. Clauses 9 10 contain PS and JW utterances with the category of identifying relational. PS states that populist economy is a strategy to improve people's welfare, while the most important policy is the improvement of national economic governance and food system. Through clauses 11-12, PS hopes that Indonesia becomes a strong country. Therefore, it is necessary to increase economic growth and national welfare. Later, JW's utterance conveys his experience of being a governor in Jakarta because JW has experienced handling and managing facilities and infrastructure in Jakarta. Clauses 13 - 14, PS stated as part of his policy is the opening of new agricultural land. Potential agricultural productive land reaches 77 million throughout Indonesia. Furthermore, JW's utterances offer the improvement of the economic growth and prosperity of the people. Clauses 15-16, PS and JW talks about the sales of strategic assets of Indonesia as a country. PS views that the sale of strategic asset of this country is extremely theoretical so that pros and cons cannot be avoided. Whereas, for JW the sale of assets such as Indosat to other parties in 1998 was because of monetary crisis experienced by Indonesia that required financial assistance to balance the state budget.

\subsection{Participant System}

Participants are elements contributing as actors and recipients of activities within the interaction. Participants in the circle of the SFL study can be all living things (human) and inanimate objects. Labeling of participants depends on the type of process used in a clause. Participants are divided into two categories namely participant I (source of action) and participant II (target/product of action). For example, in clauses with material processes have participant labels actor-goal, mental processes: sense - phenomena, relational processes: a) identifying process: Token - value, b)

Setiawan, I., Laksana, I. K. D., Mahyuni, -, \& Udayana, I. N. (2018). Transitivity in the text of Indonesian presidential candidates debate. International Research Journal of Management, IT and Social Sciences, 5(6), 114-130. https://doi.org/10.21744/irjmis.v5n6.428 
attribute: senser- attribute, c) property: owner - property, behavior: Behaver- behavioral realization, verbal process: sayer- verbiage, and existential process: existent - existential realization. This labeling process undergoes adaptation, resulting in a new label for behavioral processes and forms.

Participants are divided into three parts. First, the pattern of participants by the type of participant consists of single participants and plural. Second, the pattern of participants by category of covering consists of both human and nonhuman participants. Third, the pattern of participants based on the nature of participant consists of two forms, namely: human participants having the nature of inclusive (general) and exclusive (special) and non-human participants having definitive (definite) and non-definitive (uncertain).

Table 5

Level and Domination of Participant 1 found in Debate Text of Presidential Candidates

\begin{tabular}{|c|c|c|c|c|c|}
\hline \multirow[t]{2}{*}{ No. } & \multirow[t]{2}{*}{ Participant I } & \multicolumn{2}{|c|}{ PS } & \multicolumn{2}{|c|}{ JW } \\
\hline & & TDC I & TDC II & TDC I & TDC II \\
\hline 1 & Actor & 76 & 64 & 115 & 62 \\
\hline 2 & Senser & 37 & 85 & 58 & 42 \\
\hline \multirow[t]{3}{*}{3} & Token & 28 & 26 & 33 & 37 \\
\hline & Senser & 16 & 16 & 17 & 22 \\
\hline & Owner & 13 & 24 & 26 & 25 \\
\hline 4 & Behaver & 44 & 115 & 111 & 116 \\
\hline 5 & Sayer & 43 & 44 & 29 & 37 \\
\hline 6 & Existent & 90 & 72 & 98 & 103 \\
\hline \multirow[t]{2}{*}{ No. } & \multirow[t]{2}{*}{ Participant II } & \multicolumn{2}{|c|}{ PS } & \multicolumn{2}{|c|}{ JW } \\
\hline & & TDC I & TDC II & TDC I & TDC II \\
\hline 1 & Goal & 69 & 61 & 70 & 59 \\
\hline 2 & Phenomena & 24 & 65 & 46 & 53 \\
\hline \multirow[t]{3}{*}{3} & Value & 27 & 31 & 33 & 37 \\
\hline & Attribute & 16 & 16 & 17 & 22 \\
\hline & Property & 13 & 24 & 26 & 25 \\
\hline 4 & Behavioural Realization & 19 & 23 & 30 & 54 \\
\hline 5 & Verbiage & 32 & 23 & 13 & 26 \\
\hline 6 & Existential Realization & 39 & 7 & 11 & 5 \\
\hline
\end{tabular}

Table 5 lists the use and dominance of participants I and II. The use of participant I show that PS through CDT I is more likely to position participant I as an entity, meaning that PS tends to represent various entities in the effort to build the economy and national welfare. Then in CDT II, PS places itself more as an agent in the formulation of international political policy and national resilience. It is different with JW who are more likely to show himself as a behaver in the realization of economic development - national welfare and international politics - national resilience. The use of participant II shows that JW dominates the use of participant II. JW tends to use the role of participant II as a phenomenon, value, attribute, property, and behavior realization, whereas PS more often uses the participant II roles as goals, verbiage and existential realization. In terms of the dominant use of participant PS and JW are alike in the use of the object of an action "Goal" as the object of the actor's action in the material process.

The participants' reach consists of the reach of the main participants and other participants. The main participants are the core, while the other participants as the support or explanation in the interaction. The reach of the main participants includes both exclusive and inclusive, and single and plural participants. Meanwhile, other participants are in the form of anchor, beneficiaries, recipients, clients, and recipients. The use of the main participants and the participants of other participants in CDT I and II are presented as follows:

1) Main Participant

The use of single participants by both candidates including exclusive and inclusive single participant categorized into human and non-human covering the range of single participant used by PS in CDT I and II shows single exclusive human participant type (e.g. Pak Joko Widodo/Mr. Joko Widodo) and definitive non-human participants (e.g. Indonesia and Vietnam), whereas the use of participants by JW includes single exclusive human participants (e.g. Ibu Eli/ Mrs. Eli, Pak Abdullah/ Mr. Abdullah, Ibu Satinah/ Mrs. Satinah, and Pak Asep/ Mr. Asep) and no single nonhuman exclusive single participant is used. Then the use of single inclusive participants indicates that the PS has the 
reach of the single inclusive human participant (e.g. Saya "me" and Satu musuh "one enemy"), whereas non-human non-definitive participants (e.g. human "forest" and ancaman "threat"). Besides, JW uses single human inclusive participants (e.g. saya "me", Pemerintah "government", and Manusia "human") and non-definitive non-human inclusive (e.g. anggaram "budget", hal "matter", Infrastruktur "infrastructure", BUMN "SOEs", cara "ways", Keadaan "conditions", kekayaan alam "natural wealth", diplomasi "diplomacy", Negara "state", and soulsi "solution").

\section{2) Plural Participant}

The plural participants used by both candidates include the exclusive and inclusive plural participant with the participant category in the form of the human and non-human participant. The use of multiple participants by both candidates shows that PS has a tendency to use exclusive human participants (e.g. kami "us") and JW tends to used human plural participants (kami "us" and TKI "migrant workers"). Furthermore, the use of inclusive plural participants by PS in his text comprises inclusive human plural participants (e.g. kami "us", bapak "fathers", pasukan perdamaian "peacekeepers", rakyatnya "their peoples", negara lain "other nations", and pihak asing "foreigners") and exclusive human plural (e.g. kekayaan alam "natural wealth", , investasi asing "foreign investment", , kepentingan nasional bangsa "nation needs", , cara dan strategi "ways and strategies", program "programs", aset negara "state assets", and satu hektar "one hectare"). Whereas, JW uses inclusive human plural participants (e.g. kami "us", manusia-manusia "humans", mereka "them", and pemerintah "government") and non-definitive non-human inclusive participants (e.g. cadangan "reserves", kedua "second", 62 ton "62 tons", hal-hal "matters", masalah-masalah "problems", and tahapan-tahapan "stages").

3) Other Participants

Other participants in the PS and JW's presidential debate text include the use of reach of participant, benefactor, recipient, client, and receiver. Of the five other types of participants most dominantly used by both candidates, namely reach of participant, then followed by beneficiary participants, and recipients. More details, can be seen in table 4.6 below.

Table 6

Level and domination of the use of other participants

\begin{tabular}{|c|c|c|c|c|}
\hline Candidate & Type & Preposition & Scope & $\begin{array}{c}\text { Number } \\
\text { TDC I \& II }\end{array}$ \\
\hline \multirow[t]{5}{*}{ PS } & Reach & $\begin{array}{l}\text { Closeness of the meaning of } \\
\text { utterances }\end{array}$ & All types of the process & 153 \\
\hline & Benefactor & $\begin{array}{l}\text { untuk; } \\
\text { kepada } \\
\text { pada }\end{array}$ & $\begin{array}{l}\text { mental } \\
\text { relational } \\
\text { behavioural } \\
\text { existential }\end{array}$ & 25 \\
\hline & Recipient & kepada/pada & \multirow[t]{2}{*}{ material } & - \\
\hline & Client & Untuk & & 3 \\
\hline & Receiver & $\begin{array}{l}\text { untuk; } \\
\text { kepada/pada }\end{array}$ & verbal & 3 \\
\hline \multirow[t]{5}{*}{ JW } & Reach & $\begin{array}{l}\text { Closeness of the meaning of } \\
\text { utterances }\end{array}$ & All types of the process & 270 \\
\hline & Benefactor & $\begin{array}{l}\text { untuk; } \\
\text { kepada } \\
\text { pada }\end{array}$ & $\begin{array}{l}\text { mental, } \\
\text { relational } \\
\text { behavioural } \\
\text { existential }\end{array}$ & 35 \\
\hline & Recipient & kepada/pada & \multirow[t]{2}{*}{ material } & 10 \\
\hline & Client & Untuk & & 5 \\
\hline & Receiver & $\begin{array}{l}\text { untuk; } \\
\text { kepada/pada }\end{array}$ & verbal & 5 \\
\hline
\end{tabular}

Setiawan, I., Laksana, I. K. D., Mahyuni, -, \& Udayana, I. N. (2018). Transitivity in the text of Indonesian presidential candidates debate. International Research Journal of Management, IT and Social Sciences, 5(6), 114-130. https://doi.org/10.21744/irjmis.v5n6.428 
The use of participants by both candidates, also has the level of pronoun. PS and JW have different range of usage. PS has pronoun level of interaction with PS, that is word of Bapak (Mr.), Pak (sir), and Saudara "Brother/ Mr.". Meanwhile, the reach of pronoun used by JW against PS is in the form of Bapak (Mr.) and pak (Sir). The scheme of the use of pronoun by PS and JW can be pictured as follows (see table 1)

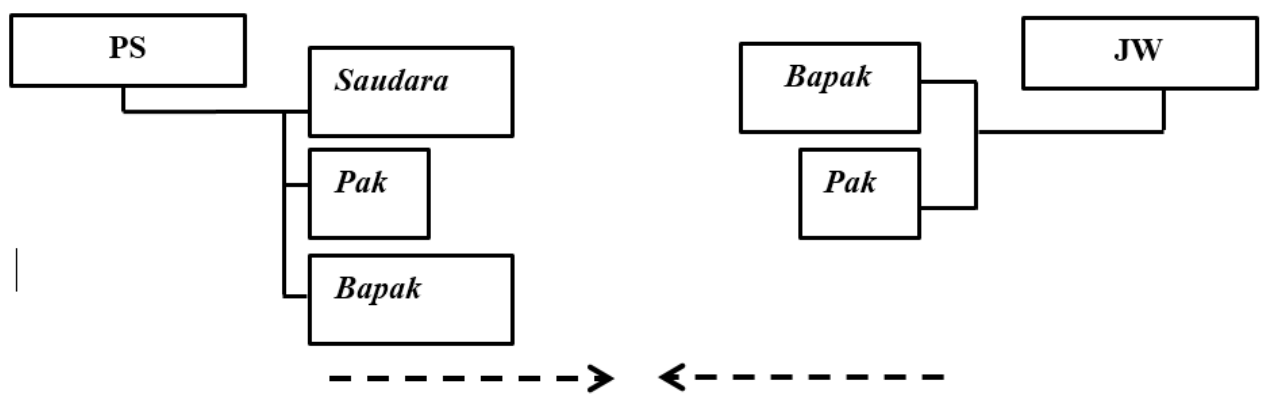

Figure 1. The Scheme of the Hierarchy of the Pronoun used by Bothe Candidates

\subsection{Circumstance System}

The reach of circumstance is the distance and the performance of policy realized over space, time, manner, nature, and the source of the process. Saragih (2006: 38) states circumcision is the environment, nature, or location of the process. Halliday (2014: 313) divides the circumstance into nine types: extent, location, manner, cause, contingency, accompaniment, role, matter and angle. In addition, there is an additional circumcision namely source.

From the results of the analysis of CDT I and II, there is a level and the scope of circumstance used by both candidates. The level and dominance of circumstance used by PS and JW can be seen in table 7 below.

Table 7

Level and Dominance of Circumstance used by PS and JW

\begin{tabular}{lccc}
\hline & Type of Circumstance & \multicolumn{2}{c}{ Number (TDC I \& II) } \\
\hline \multirow{2}{*}{ Extent: } & & Capres PS & Capres JW \\
& Time & 17 & 11 \\
Location: & Place & 1 & 6 \\
& Time & 54 & 83 \\
Manner & Place & 64 & 119 \\
Cause & & 339 & 432 \\
Contingency & & 20 & 109 \\
Accompaniment & & 40 & 19 \\
Role & 31 & 67 \\
Matter & & 56 & 117 \\
Angle & & 24 & 14 \\
Source & 3 & 5 \\
\hline
\end{tabular}

Table 7 contains the dominant level of use of Manner by JW. The total use of this type of circumstance by JW reached 432 cases. The Manner circumstance can be identified by the use of the word akan (will), harus (must), mau (want), sudah (already), and so on. The circumstantial scheme used by JW includes: manner, location of the place, role, cause, location of time, accompaniment, source, contingency, matter, time extent, place extent, and angle. Furthermore, PS has a scheme of circumstance which is: manner, location of place, role, location of time, source, contingency, accompaniment, cause, problem, time extent, angle, and place.

PS and JW also have a different range of circumstance. This can affect and determine the direction of the policies of the two candidates during the debate. The range or reach of circumstance can also show the focus of attention of 
both presidential candidates in economic development - national welfare and the promotion of international politics national security. The range or reach of circumstance used by both candidates are presented as follows:

1) The range of circumstance found in PS' debate text: a) the time extent: PS highlights the targets for the realization of his vision-mission within the five years of his leadership, b) the place of location: PS focuses on international politics on world peace preservation in conflicting areas, and Asia, and c) manner: PS puts forward the ways of being required, will / can / do, and not as a form of denial of attitudes, d) cause: PS touches on the potential issues of Indonesian youth, Indonesia's participation in various world forums, and the position of Indonesia in ASEAN, e) contingency: PS addresses the potential of creative economy, the condition of international politics of Indonesia, and the importance of improving the health sector; f) accompaniment: PS involves participants, such as JW and the public to realize their visions; g) role: PS highlights the role of participants in realizing their policies, such as weakness, speech as a waist, and as chairman of HKTI, h) problem: PS tends to highlight many work programs which are not optimally realized by a presidential candidate, as well as infrastructure issues, alusista, and dron procurement that necessarily require consideration of all related parties, i) the angle: The PS is intensively aware of the leakage level of the Indonesian state budget which must be controlled immediately and used to improve the welfare of the people, and j) source: PS states that the development of the nation and the country comes from the people, from various national economic potentials, abroad, and so forth.

2) The range of Circumstances found in JW's debate text are: a) place extent: JW observes the level of equity of development, economy and price of products in the market from Sabang to Merauke through the construction of the Sea Toll, b) location: JW mentions potential economic places such as territories in Sumatra, Java, Kalimantan, Papua, and Nusa Tenggara. In addition, JW also affirms Indonesia's trade objectives to the WTOaffiliated countries, c) manner : JW's stance in realizing its visions tends to be manifested in ways that require, deny and ignore the word "no", d) cause: JW alludes to the uneven causes of the price of eco-commodities in various parts of Indonesia, the existence of the competitive price, and the unclear price limits, e) contingency: JW highlights the development in the electricity, education and creative economics sectors; f) accompaniment: JW realizes his visions by involving the government, the army, various policies, foreign countries, and traders, g) role: JW alludes to the potential role of Indonesia as a winning nation, poor, JW states some issues in the debate, such as poverty, conflict, crisis, and the number of fissures Iran population, i) angle: JW does not explicitly express views on debate material, and j) source: JW affirms that economic development and national welfare are sourced from the people to the people, from every region of Indonesia such as Sulawesi, Java, and comes from improving the village law on village development budgets.

\section{Conclusion}

Based on the results and the above discussion, the study concluded that exposure linguistic experience by PS and JW as presidential candidates have different schemes and range of transitivity. The difference in the scheme and the range of the use of processes, participants, and circumstance. The scheme and the extent of linguistic experience exposure by both candidates on CDT I and II.

1. Schemes and range of the process: a) The high-realization process scheme contains the composition of utterances that are not different between the two candidates, namely: behavior, existential, material, and mental. However, from the level of use of the process, it shows the difference in which JW dominates the use of high realization process compared to PS does. b) The low- realization process schema contains the same schema. The composition of the utterances of both candidates categorized into low- realization processes is: identifying, possessive, attributive, and verbal. Additionally, based on the number of the use, PS more dominates the utterances with lowrealization process compared to JW does. Thus, PS and JW have the same process scheme and different process usage levels. JW more dominates the use of the high-realization process, while PS dominates the use of the lowrealization process. c) The range of the high-realization process by the two candidates shows the difference. PS has an outline of the process: 1) Material: building, working, securing, and sustaining materials 2) Mental: understanding, imagining and needing 3) Behavioral: letting, convincing, and being friendly, 4) Existential: improving, being a leak, and existing. Then JW has a process: 1) Material: building, giving, and being trained, 2) Mental: thinking, respecting, and putting forward, 3) Behavioral: doing, sustaining, doing, and working, 4) Existential: reducing, and existing.

Setiawan, I., Laksana, I. K. D., Mahyuni, -, \& Udayana, I. N. (2018). Transitivity in the text of Indonesian presidential candidates debate. International Research Journal of Management, IT and Social Sciences, 5(6), 114-130. https://doi.org/10.21744/irjmis.v5n6.428 
2. The scheme and range of realization show that: a) the scheme of participants' level used by both candidates. The use of participant I on CDT I shows that PS is more likely to position participants I as 'existent', whereas JW is more dominant in positioning participant I as 'behaver'. Then, in TDC II, PS and JW both tend to position participants I as 'behaver'. Furthermore, the second positioning of participants by both candidates indicates that both PS and JW align participants II as 'goals' in TDC I and II. b) The reach of the participants: a) The main participants consist of two types, singular, and plural. The use of single participants by PS and JW in TDC I and II tend to be single inclusive human participants, whereas the use of multiple participants in both candidates shows that PS tends to use plural inclusive human participants; moreover, JW uses non-human inclusive plural participants. b) in terms of the use of other participants indicates that JW dominates the use of other participants compared to PS.

3. The scheme and range of the circumstances indicate the use of circumstance by the PS consisting of the manner, place of location, role, time of location, source, contingency, accompaniment, cause, matter, time extent, angle, and place extent. Whereas, JW use types of circumstance as follows: manner, the location of the place, role, cause, the location of time, accompaniment, source, contingency, matter, place extent, and the angle.

Conflict of interest statement and funding sources

The author(s) declared that (s)he/they have no competing interest. The study was financed by BPPDN.

Statement of authorship

The author(s) have a responsibility for the conception and design of the study. The author(s) have approved the final article.

\section{Acknowledgments}

My gratitude is delivered to the team of examiners, Prof. Dr. Aron Meko Mbete, Prof. Dr. I Nengah Sudipa, M.A., Prof. Dr. I Wayan Simpen. M.Hum. Dr. Putu Sutama, M.S., and Dr. Made Sri Satyawati, S.S., M.Hum., for their advice, criticism, motivation, appreciation, and moral support, so that this research can be accomplished. 


\section{References}

Ajilore, O. O. (2015). Acclaims, attacks and defences in Nigerian gubernatorial debate. Discourse \& Communication, 9(1), 3-18. https://doi.org/10.1177\%2F1750481314555261

Benoit, W. L., \& Airne, D. (2005). A functional analysis of American vice presidential debates. Argumentation and Advocacy, 41(4), 225-236. https://doi.org/10.1080/00028533.2005.11821632

Bhattarai, K., Bachman, P., Conte, F., Haughton, J., Head, M., \& Tuerck, D. G. (2018). Tax plan debates in the US presidential election: A dynamic CGE analysis of growth and redistribution trade-offs. Economic Modelling, 68, 529-542. https://doi.org/10.1016/j.econmod.2017.08.031

Eggins, S. (2004). Introduction to systemic functional linguistics. A\&C Black. https://books.google.co.id/books?hl=en\&lr=\&id=sS7UXugIIg8C\&oi

Eriyanto. (2001). Analisis wacana: pengantar analisis teks media. LKiS Yogyakarta.

Eriyanto. (2009). Analisis Framing: Konstruksi, Ideologi, dan Politik Media. Yogyakarta: LKiS.

Halliday, M. A. (1985). Systemic background. Systemic perspectives on discourse, 1, 1-15.

Halliday, M. A. K., \& Matthiessen, C. M. (2013). Halliday's introduction to functional grammar. Routledge. https://content.taylorfrancis.com/books/download?dac=C2012-0-127808\&isbn=9781135983413\&format=googlePreviewPdf

Halliday, M. A. K., Matthiessen, C., \& Halliday, M. (2014). An introduction to functional grammar. Routledge.

Jones, J. \& Shận W. (2007). Bahasa dan Politik. (Sunoto et al., Pent). in Syukur Ibrahim, editor. Bahasa, Masyarakat, dan Kekuasaan. Yogyakarta: Pustaka Pelajar. Hal: 49-76.

Koussouhon, L. A., \& Dossoumou, A. M. (2015). Political and Ideological Commitments: A Systemic Functional Linguistic and Critical Discourse Analysis of President Buhari's Inaugural Speech. International Journal of Linguistics and Communication, 3(2), 24-34.

Mahsun, M. S. (2005). Metode penelitian bahasa: tahapan strategi, metode dan tekniknya. PT RajaGrafindo Persada.

Miles, M. B., \& Huberman, A. M. (1992). Analisis data kualitatif.

Orwell, G. (2013). Politics and the English language. Penguin UK. https://books.google.co.id/books?hl=en\&lr=\&id=TkYBOMBRmhkC\&oi

Potter, L. (2016). Ideological representations and Theme-Rheme analysis in English and Arabic news reports: a systemic functional approach. Functional Linguistics, 3(1), 5. https://doi.org/10.1186/s40554-016-0028-y

Purba, R. A. N. (2015). Berperang dengan Saudara Sendiri. View in (Google).

Saragih, A. (2006). Bahasa dalam Konteks Sosial: Pendekatan Linguistik Fungsional Sistemik terhadap Tata Bahasa dan Wacana. Medan: Sekolah Pacasarjana Universitas Negeri Medan.

Sinar, T. S. (2012). Teori \& Analisis Wacana: Pendekatan Linguistik Sistemik Fungsional. Medan: Mitra Medan.

Sudaryanto. (2015). Metode dan Aneka Teknik Analisis Bahasa: Pengantar Penelitian Wahana Kebudayaan secara Linguistik. Yogyakarta: Sanata Dharma University Press.

Wareing, S. (2007). Apa Bahasa itu dan Apa Peranannya? (Sunoto dkk., Penerj.).in Abd. Syukur Ibrahim, editor. Bahasa, Masyarakat, dan Kekuasaan. Yogyakarta: Pustaka Pelajar. pp: 1-25.

Young, L. (2011). Systemic functional linguistics. https://doi.org/10.4324/9780203835654.ch44

Setiawan, I., Laksana, I. K. D., Mahyuni, -, \& Udayana, I. N. (2018). Transitivity in the text of Indonesian presidential candidates debate. International Research Journal of Management, IT and Social Sciences, 5(6), 114-130. https://doi.org/10.21744/irjmis.v5n6.428 


\section{Biography of Authors}

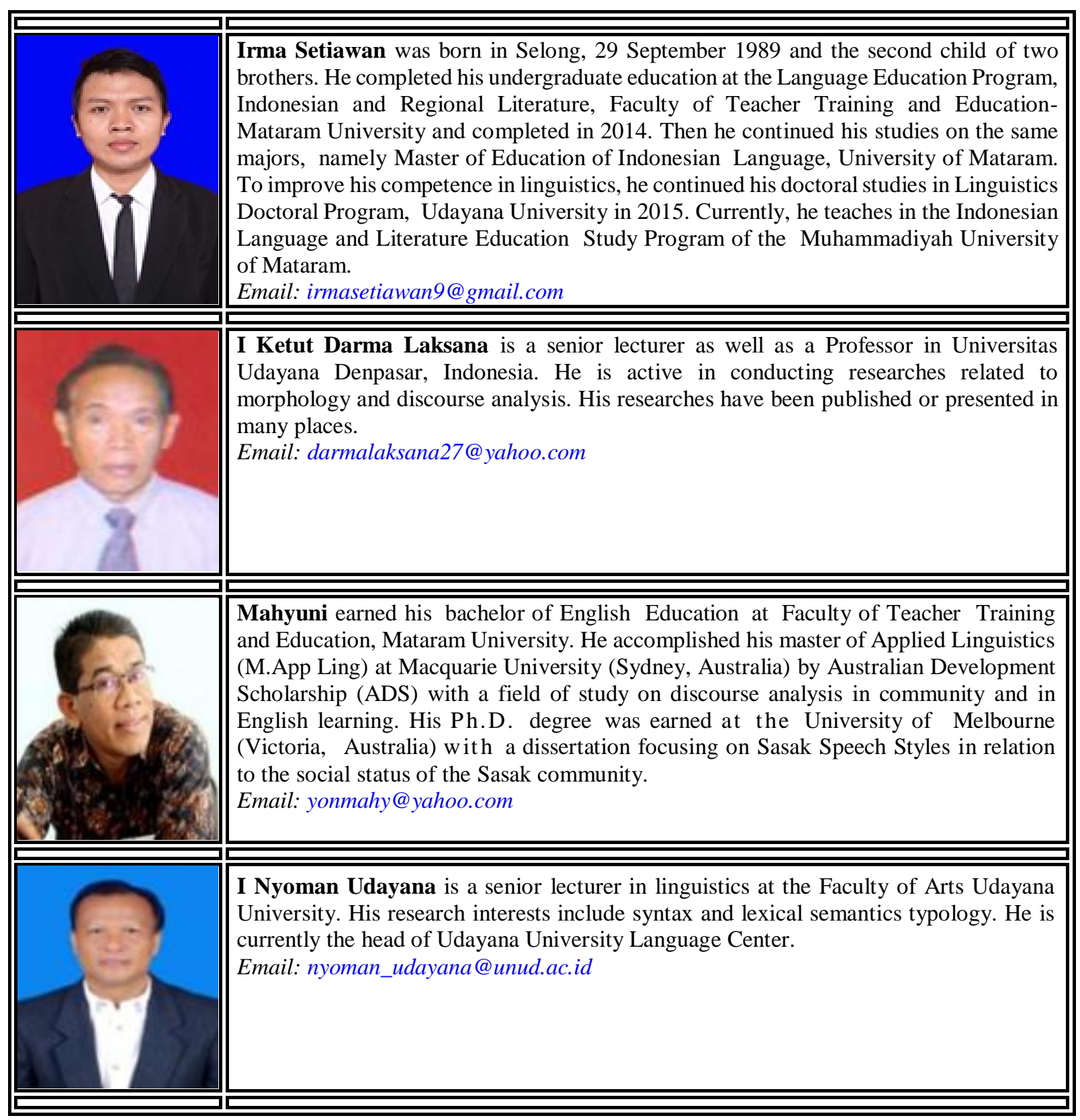

